\title{
An educational intervention focused on teaching Qualified Empathy to social work students in Finland
}

\begin{abstract}
Purpose - The main goal of the one semester long intervention for first-year Bachelor of Social Services students was to enable them to increase their awareness of a variety of cultures and practices encountered in social pedagogical work and to support the development of their ability to interact empathically with clients.

Design/methodology/approach - The aim of this article is to describe an educational intervention focused on teaching Qualified Empathic skills to social work students in higher education at Metropolia University of Applied Sciences in Finland. We introduce the concept of Qualified Empathy to describe professional empathic working skills and define it as: Qualified Empathy requires compassion for empathic action and it includes the ability for professional self-reflection, emotional skills and a healthy set of boundaries. Qualified Empathy encompasses the ability to tell the difference between sympathy and empathy, as it includes the capacity to use compassion to act in an empathic way in professional contexts (Raatikainen et al., 2017). The study was a case study, designed to explore the students' experiences of their one semester long educational intervention $(n=20)$. Our research question was: How do students construct Qualified Empathy as a dimension of their own professional expertise?
\end{abstract}

Findings - The results of the study demonstrate the progress areas of the students' Qualified Empathy skills. The development stages in the three progress areas are: (1) from emotional reaction to emotional response, (2) from understanding to empathic acting and (3) from client perspective to a more systemic approach. Implications of the results for Social Services students are discussed.

Research limitations/implications - In this study, as in all studies, some limitations need to be taken into account. One limitation of this study is the size and "nature of data". Secondly, challenges with the concept of Qualified Empathy need to be addressed and more research is needed to define it more concretely. Even so, as it is a new concept, we need more discussion on the differences in the definition of empathy and Qualified Empathy. However, this study offers one new perspective for discussion which is the need for empathy training, in social work education practices and in the field. An important ethical aspect of research emphasizes that its implementation must not be to the detriment of the people being researched (Juuti and Puusa, 2020, pp. 168).

Practical implications - Our findings demonstrate that educational interventions can improve students' empathy skills to more qualified skills. We emphasized that maintaining the skill demands continuous reflection as a lifelong process. This article provides an overview of an educational intervention to improve students' Qualified Empathy skills and suggests a definition for educators to frame the teaching of professional empathy or empathy in a professional context - especially in the social work context. Furthermore, with this educational intervention in social work, we offer a way to support the students to - not only - have a more professional approach to empathy but also to find a way to establish a more emotionally sustainable environment for professionals in social services. It is essential for social work education to focus on the growth of Qualified Empathy in students through supervision and guidance which supports their professional competence. By doing so, we contribute to the development of more sustainable working environments in the social work context.

(c) Eija Raatikainen, Leigh Anne Rauhala and Seija Mäenpää. Published by Emerald Publishing Limited. This article is published under the Creative Commons Attribution (CC BY 4.0) licence. Anyone may reproduce, distribute, translate and create derivative works of this article (for both commercial and noncommercial purposes), subject to full attribution to the original publication and authors. The full terms of this licence may be seen at http://creativecommons.org/licences/by/4.0/legalcode

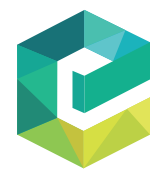

Journal of Applied Research in Higher Education Vol. 14 No. 1, 2022 pp. $409-423$

Emerald Publishing Limited $2050-7003$ DOI 10.1108/JARHE-11-2020-0404 
JARHE 14,1

\section{0}

Social implications - Professional empathy is seen as an important factor in building a socially sustainable society from the perspectives of employees, clients and patients. We noticed that it is important to allow time and space for the learners to internalize the concept of Qualified Empathy. When we allow for this, students begin to recognize and assign more value to it and, as we suggest, they become more adept in their interactions and work with clients.

Originality/value - The study was a case study, designed to explore the students' experiences of their one semester long educational intervention $(n=20)$. Our research question was: How do students construct Qualified Empathy as a dimension of their own professional expertise? The results of the study demonstrate the progress areas of the students' Qualified Empathy skills. The development stages in the three progress areas are: (1) from emotional reaction to emotional response, (2) from understanding to empathic acting and (3) from client perspective to a more systemic approach. Implications of the results for Social Services students are discussed.

Keywords Qualified Empathy, Higher education, Social work, Learning and teaching Qualified Empathy Paper type Research paper

\section{Introduction}

In our historical and political era, social work education is carried out to help students develop their sense of connection to the people they serve as well as the skills to assess their needs without being swallowed up by complex problems and difficult ethical situations. Our modern age is challenging, both globally and locally, and we need to ponder how we could become, or remain, connected to one another, remain respectful of one another and still be able to have an opinion of our own which reflects our personal values. Although, social work is a high stress profession that involves working with people in distressing circumstances, as observed by, for example, Stanley and Mettilda (2015), it is too often overlooked that we need to support students in building their self-care skills through education (Newell and NelsonGardell, 2014). Empathy training should not be taken for granted during studies. This is one of the main reasons why the benefits of empathy need to be recognized and explored more thoroughly.

In general, it can be concluded that empathy includes many benefits. As a way of example, studies have shown (Gerdes and Segal, 2011; Howe, 2013; Sinclair et al., 2017) that clients who experience empathy while working with professionals manifested better results and higher levels of effectiveness. Empathy was found to provide protection against burnout and to improve the balance of professionals' roles (Wagman et al., 2014). Based on these findings, Wagman et al. consider that studying empathy is justified and should be a core part of social services studies. Furthermore, the lack of information and training resources focused on professional self-care (Newell and Nelson-Gardewell, 2014, p. 432) support our position that there needs to be more emphasis on the development of empathy in social work education. In order to develop professionalism within the social sector, educational policymakers need to assist students to develop better trust-based interactions, emotional skills and empathy. It is important for social work education to focus on empathy in students through supervision and guidance, in order to support their professional ability and develop more sustainable working environments in the social work context.

To sum up, there is a significant need for empathy skills in the world, especially in the social and health field. Currently, empathy is being taught in many ways, but because in the rapidly changing world we face new complicated global problems (such as immigration, climate change and recently, the COVID-19 pandemic), this is not enough.

The aim of this article is to describe the results of an educational intervention focused on teaching Qualified Empathy to social services students in higher education in Finland. We explore how Qualified Empathy is experienced and developed by students, as an optional framework for professional empathy, rather than a skill set as such. The recognition of the feeling of Qualified Empathy, and how to use it ethically and effectively to support the 
development of the relationship with the client and opportunities for supportive guidance between the worker and the client were some of the objectives of the educational intervention. In addition, we wanted to create a mental framework for professional practice.

\section{What is Qualified Empathy, why do we need it, isn't empathy enough?}

This article is based on the concept of Qualified Empathy. Introducing this concept previously (Raatikainen et al., 2017), we characterized a Qualified Empathy professional as a practitioner with the ability to frame any client interaction by using accurate or targeted empathy. Qualified Empathy requires compassion for empathic action and includes the ability for professional self-reflection, emotional skills and a healthy set of boundaries. It contains the ability to tell the difference between sympathy and empathy and the ability to use compassion for acting in an empathic way. Such empathy is not only for the clients but also for the professionals themselves and the environments surrounding the interactions. In other words, our understanding of the Qualified Empathy professional is someone who has empathic skills and compassion toward themselves, colleagues, clients and the environment. Qualified Empathy is more of a mindset or work orientation than a method that is rooted in ethical thinking. An empathic social worker is able to be a mirror to others and adjust his or her interactions without immersing themselves into the other's emotional world or context.

Qualified Empathy has its roots in the conventional understanding of the term empathy. According to Rogers (1975), being empathic involves understanding the inner world of the other. For the professional, this involves accuracy of understanding and control of personal emotional components while "feeling " as if" they were the client" during the interaction. If we lose the "as if" state, we would only determine through cognitive recognition but we would not achieve compassionate recognition (Rogers, 1975). Rogers (2007) pointed out the importance of empathic understanding in a counseling relationship. Gerdes and Segal (2009) refer to Decety and Moriguchi's outline of the four components of empathy: (1) affective sharing or the experience of similar emotions between the self and other; (2) self-awareness which recognizes that although there is temporary identification between the self and other, there is no confusion between the self and the other; (3) mental flexibility or the ability to cognitively imagine another's situation "from the inside"; and (4) emotion regulation, which utilizes regulatory processes to modulate the subjective feelings, associated with emotion. Without the possession self-awareness of others and the ability to mentalize (Fonagy et al., 2004), an individual will have difficulties to imagine oneself in, another's position (Iacoboni, 2008).

In our exploration of the literature, empathy as a socio-emotional (social affective) phenomenon is often based on interaction and relationship (Cunico et al., 2012). Empathy is an essential part of a functioning human relationship and manifests itself as an ability to recognize when the other person needs support (Thompson and Woods, 2000, p. 160). Rogers (1961) (in Thompson and Woods, 2000) said, "Empathy requires the emotional capability to commit to understanding another person's world, but it does not mean that we should "take all the other's emotions as our own'”. Empathy recognizes a sense of equality (Thompson and Woods, 2000). When we look into it from a neurobiological, "micro" perspective, research on mirror neurons has shown that our bodies respond to another person's emotions or actions, "as if" we would feel a degree of that emotion ourselves (Decety and Jackson, 2004). We have a drive to imitate others from birth and it never decreases (Iacoboni, 2008) but continues to develop as we gain linguistic abilities (Eckerman and Didow 1996 in Gerdes and Segal, 2009). According to Arnold (2014), in accordance with our view, empathic intelligence is a complex concept beyond the neurophysical, including both intersubjective (interactions between subjects) and intra-subjective (experiencing within subjects) aspects. 
JARHE 14,1
Professional empathy is often believed to occur by itself, unconsciously and intuitively. Unfortunately, that is not often a realistic way to see it. According to Grant et al. (2014) we take students' empathy skills for granted, and expect that they are able to demonstrate an awareness of their own emotional resilience and the impact of their actions when working with clients. We expect them to be able to use their own experiences in interactions while managing their own safety and wellbeing. As work within the social services sector is largely interactive in terms of creating relationships and trust-based interventions these skills are paramount for the workers to support both the client's and their own wellbeing. For example, according to Lloyd et al. (2011), however, social workers are identified as being at risk for experiencing stress and burnout, because social work is strongly client-based and often involves complex social situations and conflicts.

Too often, we as educators assume that social work students have a "natural skill" for empathy and altruism. Still, many ways to teach empathy exist. For example, studying outside of the classroom, such as Service Learning projects (Engaged Scholarship) (Trad, 2013) or by movie viewing and based on reflection (Briggs et al., 2012). Further methods include literature circuit (Shapiro et al., 2004), learning of better communication skills (Winefield and Chur-Hansen, 2000) or self-assessments, i.e. different types of measures of empathy in self-evaluation (e.g. The Empathy Scale for Social Workers, ESSW) (King and Holosko, 2011). In addition, creative methods have been explored and used while teaching empathy to students.

In a changing and unpredictable world, we need a more systematic, professional, approach to empathy. A people-to-people perspective is insufficient, we need a wider perspective in order to create a more sustainable future for all. Qualified Empathy offers a wider perspective; it includes social pedagogical and eco-social approaches for empathy in professional contexts. In order to establish a truly sustainable definition and application of Qualified Empathy, we need to look at the larger context of wellbeing as part of the living environment.

\section{Qualified Empathy - elements from the social pedagogical and eco-social viewpoints}

Matthies et al. (2001) define their eco-social approach as one that emphasizes the reciprocal relationship between the living environment, which includes the physical and social (meso contexts), cultural-historical environments and human welfare (macro contexts). This has to take place during the processes of exploration, curriculum development, teaching, reflecting and in dialogue with students and colleagues. We wanted to develop a Qualified Empathy concept to include more of the eco-social and social pedagogical dimension to balance the mental and neuro-biological dimensions of the concept. Because of the rapidly changing world and its deepening challenges, we need to put attention to environmental, communal and global issues - in the context of empathy. A wider concept in the professional context is needed to secure a more sustainable world for the next generations. We wish to include a more diversity-sensitive dimension, which would also embrace societal wellbeing, as opposed to a casework model.

According to Salonen and Konkka (2015), in order to achieve true wellbeing, we need to consider what is good for human beings, based on our values and on our interdependence on the ecological, social and economic aspects of life. If we truly want to operate in an empathic manner with our clients, we need a multi-dimensional empathic perspective that includes, for example, the surrounding systems such as the ecosystems where our clients live, the physical and psychological systems, as well as the systems supporting human rights and social justice and the surrounding economy. When working as Qualified Empathy professionals, we work with diverse groups of people in complicated situations and contexts, which are interdependent upon one another. From the social pedagogical perspective, the German 
term "Haltung" (ethos, mindset or attitude) used by Eichsteller (2010) is understood as the professional's ability to be emotionally connected to others and a profound respect for their human dignity. Returning to the foundations of empathic practice, the term encompasses Roger's core conditions of congruence, empathic understanding and unconditional positive regard. Haltung is at the core of the "tree" which represents social pedagogy's growth and development because of its roots in societal circumstances, theoretical influences and national cultural contexts that grow up and flower as a result of dialogue, reflection and practice. The concept refers to a holistic theory, which utilizes knowledge from all of these domains to assist people in their life situations, respecting their personal knowledge, experience and strengths within the micro, meso and macro contexts. The Qualified Empathy professional, utilizing a social pedagogical perspective, is concerned with wellbeing, quality of life and positive experiences, as well as holistic learning, relationships and empowerment. We believe these ideas correlate well with Salonen and Konkka's (2015) idea of "true wellbeing" and together form a more diversity-based, societally sensitive model for empathy.

\section{Teaching and facilitating as learning processes of Qualified Empathy - an educational intervention}

A professional level of empathy requires practice and development through guided learning (Hepworth et al., 2018). When facilitating students to refine their understanding and fine-tune their use of empathy, we must first help them to recognize that empathy is different from sympathy. According to Howe (2013), empathy resonates with, while sympathy engenders concern for another. He suggests that "whereas empathy puts me in your emotional shoes, sympathy simply tells you that I've walked there too. Sympathy is me oriented; empathy is you oriented." Sinclair et al. (2017) looked at just this distinction by asking how cancer patients experienced the difference between sympathy and empathy from their caregivers. They established that sympathy involves feelings of pity for the other's adversity while empathy involves the attempt to understand, share and respond accurately to another person's feelings and experiences without judgment. The authors go on to discuss how sympathy and empathy differ and how compassion is, in the end, the most effective and wellreceived response from the client's point of view. Compassion takes empathy one-step further due to its proactivity. In research with clients, Sinclair et al. (2017) found that according to client reports, compassion was defined as "a deep awareness of the suffering of another coupled with the wish to relieve it". Following from this, education needs to develop the student's and/or the professional's ability to come alongside the individual and feel as well as act through subtle acts of kindness that are not necessarily part of the professional's job description. In the context of teaching and learning empathy, training supervisors are concentrated on verbal and written reflection focusing on recognizing theory in practice, but the experiential "felt" dimension is not as often explored as a part of training situations. We used experiential learning methods (Passarelli and Kolb, 2012) in order to address this missing component.

Our educational intervention was based on ways of teaching empathy using aesthetic methods as discussed with Austring and Sørensen (2006), Austring et al. (2009) during our Nordplus project in 2015-2017. We introduced first-year bachelor of social services students to the concept of empathy through theory lectures, literature readings, discussions and practical application during internships. Guided by Kolb's experiential learning theory (1984), students practiced interactions with peers during class and then with clients supported by their field supervisors. Aesthetic methods, such as visual arts, physical education and drama aimed to develop the students' sense and awareness of their own individual feeling of empathy. The foundation for the aesthetic teaching method came from Austring and Sørensen's (2011) idea of creating an activity where impressions of the world 
JARHE 14,1 are transformed into sensuous symbolic form. This includes reflection, which makes it possible to process experiences and communicate about the complex world as well as well as those aspects of the impressions which cannot be verbally expressed (Austring and Sørensen, 2011). Throughout the process and in connection with the continuous communication it is possible, as a result of the aesthetic method used, to be able to mirror oneself and one's understanding of the world (Austring and Sørensen, 2011; Räsänen, 2008) and, in our teaching, the student's understanding of empathy. Austring and Sørensen (2011) state that the aesthetic mode of expression contains subjective interpretation of the world, which enables communication about feelings in particular, and is potentially able to express thoughts and knowledge that we are not capable of putting into words and thus capture in discursive language. By using aesthetic methods, we wanted to offer the students a place where they could reflect on their thoughts about the "feeling of empathy" (meta-cognition) and how they might express it in a non-verbal way. This led to the next step of helping them to find the words for these feelings later during reflection. We wanted to encourage them to construct their own understanding of Qualified Empathy as an effective and protective skill. Reflection is needed (Schön, 1987) for development of a better professional.

At the beginning of the teaching intervention, during the Individual and Community Counseling course, students had an aesthetic learning task (storytelling, which focused on listening to and then sharing reflections on a story told by migrant children of crossing the sea to Europe fleeing war) to start focusing on their own individual "feeling of empathy". The Supporting Daily Life module was designed to continue the process and to deepen the students' individual, multidimensional understanding of empathy as a felt experience and its nature as a professional tool.

In visual arts, ideas and images are usually inscribed in material and that gives them a feeling of at least semi-permanence. They enable us to inspect our ideas more carefully. The works we create speak back to us and enable us to "see what we have said" (Eisner, 2002). Keeping these thoughts, and Kolb's theory on experiential learning in mind, the students were given several aesthetic methods tasks during the education intervention. We introduce here an example of a visual art method task that was implemented in the beginning of the education intervention shortly after the students had been introduced to theoretical knowledge on empathy.

The task focused on the "feeling of empathy" itself and its visual art's technical setting was to make big paintings in small student groups by using water-soluble gouache-paints with various sizes of brushes. Sharing experiential understanding of the feeling empathy was the focus: How to express your own understanding of "feeling empathy" by means of visual symbolic language, colors, color tones, lines and brush traces? How to share and communicate the feeling of empathy together? What kind of qualities of empathy could be found? It was very important to offer a safe learning environment where the learners could feel as free to express themselves as possible. The participants were given the opportunity to refuse to participate in the activity at all stages of the process when they felt they needed to. All students wanted to take part in the tasks.

The participants were asked not to talk during the painting activity but to give a nonverbal visual form to their feelings and to see how their individual understandings were communicated on the group's common painting. When they were ready, the whole group shortly reflected on their experiences. The learners described the task as challenging in the beginning but soon working together on the painting had generated a holistic process, where unspoken and felt qualities of empathy were found together. Looking at the paintings helped the painters to recap the ideas and thoughts that had come into their minds throughout the silent painting process. Sharing complex emotions as well as the "unspeakable" (Austring and Sorensen, 2011) helped the participants to find new aspects and words to describe empathy and enriched their individual and shared understanding of "empathic feeling". 
Methodology and implementation of study

Typically, case studies involve multiple methods of data collection (Robson, 2012). Additionally, in case studies, the "case" can be an individual, group, situation or even an organization. According to Yin (2009) "case studies are a strategy for doing research which involves an empirical investigation of a particular contemporary phenomenon within its real life context using multiple sources of evidence". In our study, the case was a student group at Metropolia University of Applied of Sciences in the Social Services Degree Programme in Helsinki. Like Hakim (2000) states, in case study research the focus can be on "studies of organizations and institutions and examples of processes of change". Our research question was: How do students construct Qualified Empathy as a dimension of their own professional expertise?

We collected data by using open questionnaires, learning diaries and written documentation related to the final internship (see Figure 1). The intervention had four student activity phases. As the first data collection point (1), the pre-assignment comprised an open questionnaire prior to the Individual and Community Counseling course. The questionnaire included six thematic areas:

(1) Meaning of empathy in social work,

(2) Abilities of an empathic person,

(3) Most important characteristics of an empathic person,

(4) Students' assessment of their own qualities (in relation to previous areas),

(5) Students' assessment of missing skills,

(6) Example of an empathic moment in social work.

The second data collection point (2) was an individual report after the theory lectures at the beginning of the intervention. The third data collection point (3) was the final work practice individual report based on the students' work practice at the end of the intervention. The final data collection point (4) took place at the end of the semester using an open online
Teaching

Qualified

Empathy

\section{Data collection: QUALIFIED EMPATHY LEARNING PROCESS IN ONE SEMESTER}

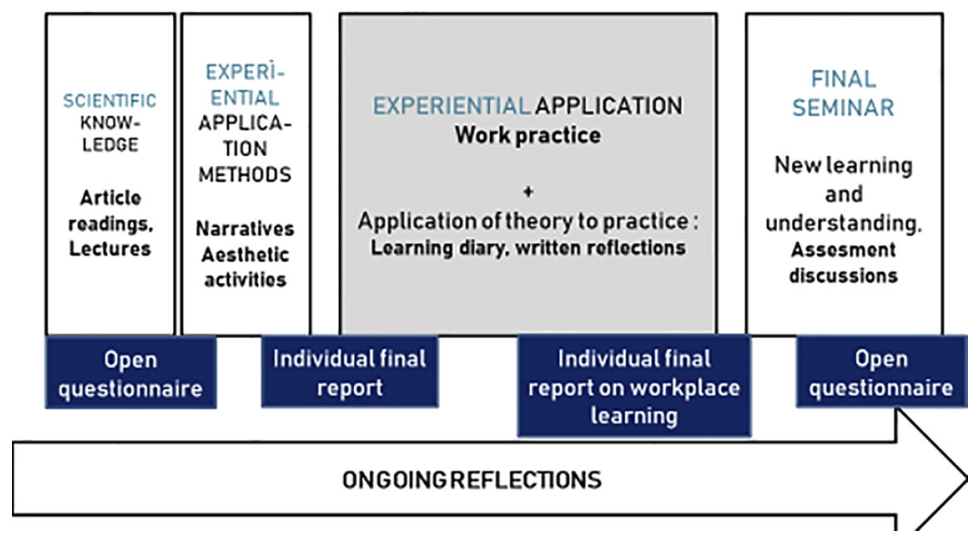

Figure 1 .

Data collection during educational intervention. The white boxes illustrate student activity phases during the process. The grey box is the student work practice and the blue boxes indicate the four data collection points (1-4) 
JARHE 14,1 questionnaire. The same questions were used as at the beginning of the Individual and Community Counseling course, with the exception of the last question on self-reflection "How aware of your internalization of "Qualified Empathic skills' were you, in the case example?"

Students were informed of the research during the initial theory course; both oral and verbal permissions were received from the participants when they filled in the questionnaire. We followed the Finnish National Board on Research Integrity and our organization's guidelines for good practice. https://tenk.fi/en/advice-and-materials/guidelines-ethicalreview-human-sciences. In our questionnaire, we included information on how and where the data would be used.

Good scientific practices and research's ethical principles were followed in the acquisition and analysis of the research material (Walby and Luscombe, 2017). In our study, student participation was voluntary, their consent was confirmed and they remained informed as we provided sufficient information about the study throughout its duration. The research material was anonymized and oral permission for the study was obtained from the institution's area manager.

The acquisition of the research material was carried out by researcher triangulation (Robson, 2012). In our study, it meant that all three authors participated in gathering relevant literature and data analysis. Initially, (1) each author analyzed the data independently, followed by (2) synthesis and (3) the results. The reliability and trustworthiness of the research and its results were ensured by the research team's numerous discussions about the results. Preliminary results were also presented in several seminars in order to obtain feedback and foster interaction with a wider audience.

\section{Participants and analysis}

The participants were 20 first-year undergraduate social work students, between 18 and 30 years of age, taking part in the Individual and Community Counseling and Supporting Everyday Lives courses. We followed the student groups' development of their empathy skills during the spring of 2018. As detailed above, data were collected in those two courses, four times during the education intervention, lasting one semester. The data consisted of (1) open electronic questionnaire before the course, (2) individual final report, (3) individual final reflection on work placement learning and lastly (4) an open electronic questionnaire at the end of the semester (during the Supporting Daily Lives course, after the work placement).

The data analysis was based on students' writings, online questionnaires and internship reports, using an abduct approach and theory-based content analysis. For analysis we adopted categories of self-reflection, emotional aspects and action. These elements are connected to the students themselves, colleagues, clients and the environment. Data were read repeatedly in order to categorize the data into smaller parts. After categorizing the data into main and sub-categories, the results were generated. Table 1 shows examples of data gathered.

The analysis was performed in two stages:

(1) The first stage was a thematic reading of the data. Our category themes followed the research question and keywords as well as Theory-related material (Ryan and Bernard 2003; Robson, 2012). The analysis keywords and perspectives were based on our previous review article (Raatikainen et al., 2017).

(2) The second stage was content analysis. In this stage, we gave the students "space" to hear something new, coming from outside the Qualified Empathy definition. 


\begin{tabular}{|c|c|c|c|}
\hline Example & Subcategory & $\begin{array}{l}\text { Main } \\
\text { category }\end{array}$ & $\begin{array}{l}\text { Teaching } \\
\text { Qualified }\end{array}$ \\
\hline $\begin{array}{l}\text { "To try not to judge the client based on their life } \\
\text { choices or the situations they are in, instead focus } \\
\text { on their goals, and intentions to get out of those } \\
\text { situations" }\end{array}$ & Not to judge, but help with life goal & $\begin{array}{l}\text { Self- } \\
\text { reflection }\end{array}$ & \\
\hline "For me, key words are ability to play different & \multirow{2}{*}{$\begin{array}{l}\text { Ability to act in different roles and } \\
\text { understand matters from many points } \\
\text { of views }\end{array}$} & & 417 \\
\hline $\begin{array}{l}\text { roles, openness, understanding, sensitivity, } \\
\text { reflection, involvement, respect, self-awareness, } \\
\text { perspective, purpose, decoding, warmth, } \\
\text { compassion, imagination, flexibility, subjectivity" }\end{array}$ & & & \\
\hline $\begin{array}{l}\text { "I did not know by then, how to use empathy in a } \\
\text { healthy way, and I was so overwhelmed by the } \\
\text { emotion I felt by then" }\end{array}$ & Balance of emotions & $\begin{array}{l}\text { Emotional } \\
\text { aspect }\end{array}$ & \\
\hline "I think that I developed further my emphatic & Using different roles and professional & Action & \multirow{5}{*}{$\begin{array}{l}\text { Table 1. } \\
\text { Examples of student } \\
\text { data acquired from } \\
\text { their writings classified } \\
\text { into the adopted main } \\
\text { and sub-categories of } \\
\text { Qualified Empathy }\end{array}$} \\
\hline $\begin{array}{l}\text { abilities by letting myself play different roles with } \\
\text { different people and communicate in all possible }\end{array}$ & techniques & & \\
\hline $\begin{array}{l}\text { ways, mirroring, talking, physical contact, } \\
\text { plaving" }\end{array}$ & & & \\
\hline "The other important thing I learned had to do with & Qualified Empathy needs action & & \\
\hline $\begin{array}{l}\text { Qualified Empathy, which ultimately results in } \\
\text { action” }\end{array}$ & & & \\
\hline
\end{tabular}

Due to the relatively small data sample, we concentrated on the content of the data and not only compared pre- and post-intervention results, but transformations as well. We also studied all data as a whole, from the theoretical point of view in addition to content analysis.

\section{Results}

According to our results, there were three "progress elements" as outcomes of the learning process, where we recognized how empathic skills could be improved during the intervention targeting the development of Qualified Empathic skills. After the two readings and analysis stages, students' internalization process leading to Qualified Empathy from empathy was thus categorized into three areas of progress: (1) from an emotional reaction toward an empathic emotional response, (2) from understanding to empathic acting and (3) from a client perspective to a more systematic approach, including the workers themselves, co-workers and a global dimension, see Table 2:

\section{Result 1. from emotional reaction to emotional response}

Emotions are fundamental in developing Qualified Empathy skills. Our results showed that, awareness and self-regulation of one's own emotions were crucial for this

\begin{tabular}{|c|c|c|}
\hline $\begin{array}{l}\text { Parts/elements of } \mathrm{QE} \\
\text { (learning process) }\end{array}$ & $\begin{array}{l}\text { From } \\
\text { Empathy }\end{array}$ & $\begin{array}{l}\text { To } \\
\text { Qualified Empathy }\end{array}$ \\
\hline 1 & $\begin{array}{l}\text { Emotional } \\
\text { reaction }\end{array}$ & Empathic emotional response \\
\hline 2 & Understanding & Empathic acting \\
\hline 3 & $\begin{array}{l}\text { Client } \\
\text { perspective }\end{array}$ & $\begin{array}{l}\text { Systematic empathic approach (workers themselves, co- } \\
\text { workers, global perspective) }\end{array}$ \\
\hline
\end{tabular}

Table 2.

The result categories as areas of learning progress from empathy to Qualified Empathy 
JARHE 14,1

development. Students stated that Qualified Empathy skills meant more than emotional reactions toward their clients' emotions; also, an emotional response from the professional was needed;

Being aware of myself and where do I stand, and of the client's situation as a separate emotional case, and trying to stay in touch with my emotions while reading the client's emotions.

I think that I've been able to develop my skills at being more sensitive to others and their specific needs. Letting go some of my own sensibilities in order to help others.

Do not want a repetition of their feelings, they need someone who puts a fresh perspective on them and offers a rational, emotionally unbiased point of view.

I feel that my interactions with emotionally charged people and situations have improved. I've been able to regulate my "distance", speech patterns and emotional state better, to name but a few.

Even though many students mentioned the importance of emotions, only a few of them thought that an emotional response was also needed. Some of them described action and response, without mentioning the emotional component. As part of Qualified Empathy, emotions are seen to have a significant role; to recognize the emotion which then informs an accurately targeted action. In other words, emotional action is needed for Qualified Empathy as professional action. According to the results, for some of the students the benefits of the intervention were that they gained a deeper understanding of this, and the ability to use it in practice with a client.

\section{Result 2. from understanding to empathic acting}

Based on open answers, students described many different ways to see and understand empathy before and during the course. One example was that students "did not know how to deal with their own emotions" or being over empathic and maybe they "felt sorry", but during the course they realized that it is the professionals' responsibility to "create a safe empty space (Ruben 2015) for connection”. Additionally, students talked about boundaries - how to set boundaries for clients and help clients to gain skills to help themselves rather than giving ready solutions to clients. During the intervention, students became more aware of their own empathy skills; keeping the focus on the other person and reflecting afterwards. They began to separate their own emotions from their client's emotions;

What I have learned about Qualified Empathy by the end of this course — because they are crucial for accurate empathy in order to avoid empathic distress.

Still, it was not always easy for students to reflect on their actions, as they can often be too hard on themselves. One student described the situation like this:

I have tried not to be too troubled about my self-criticism and see this as a process of improvement, because it can be a sign of learning.

A minority of students reported that it was important to share emotions with their colleagues. We see this as an area for further support as this is a part of Qualified Empathy; it is not just with a client, but also between colleagues:

I think it is important to be open and not ashamed about my feelings with the colleagues in the place where I will work.

Empathy needs action. Based on the students' writings, they felt that it was very important that when talking about empathy as a professional skill, as Qualified Empathy, some kind of action has to be involved:

The other important thing I learned has to do with Qualified Empathy, which ultimately results in action. 
Additionally, some of the students were more focused on action, in other words, they felt that action was always needed for Qualified Empathy. They felt that simple understanding was not enough and there had to be an action component as well, even if it was just eye contact with the client. This was the difference between empathy and Qualified Empathy, which was discovered during the course:

Acting or doing something with the empathetic response is a key part that I had never thought about before this course and reading this article. It now makes totally sense. If one has an empathetic response without any action, the response is irrelevant.

The importance of action was new to me.

Students described practical situations; giving examples of their empathic actions in practice. Instead of observing alone, or just understanding, they acted. It seemed that students thought that empathy was less effective without the conscious action on empathy:

I decided to do the empathic action rather than passively continue to observe the situation!

It was typical that during the intervention and especially after the students' work placement experience, there was evidence of a difference in the students' way of describing their developed Qualified Empathy skills.

\section{Result 3. from client perspective to a wider systematic empathic approach}

According to the results, this part was not so obvious for students. Some of them pointed out that it is important to see things from a wider point of view, or they were able to describe things from a more systematic empathic perspective. However, it was not easy to recognize the communal or a more global perspective of empathy. As part of Qualified Empathic skills, it is beneficial to see and act empathically from perspectives that are more systematic:

In addition, this showed to me that in the everyday life, it is easy to fall into the sympathetic response.

I have noticed the importance that children gave to their ability to write their own name and I noticed how they were finding ways to express their identity with it. Therefore, I facilitated the process by using stickers, medals, helping them to write at least the first letter to identify themselves. The children were fulfilled and proud of their own achievement. They were able to identify themselves with a common symbol that had meaning to their community.

\section{Summary of results}

Students saw the framework of Qualified Empathy as a helpful professional and theoretical tool, helping them to relate their learning experiences to their development, and their way of working professionally and empathically in practice. Many pointed out that using the theoretical framework was beneficial and the concept of accurate or Qualified Empathy was easier to internalize as a tool for action. It helped them to create some distance from the "personal part of the empathy".

The aim of the intervention was to help students internalize the deeper skills of empathy or Qualified Empathy; we believe we achieved this. Qualified Empathy is a professional approach, to reduce professionals' risk for burnout and to increase awareness of the risk of inappropriately intense empathy in client relationships.

At the beginning of the process, students described empathy as "understanding" and "getting into the other's shoes", but after the intervention, there was a significant qualitative difference in the students' way of describing and giving meaning to empathy in the social work context. It became more professional, with a more reflective approach. During the first progress step, from understanding to acting, it seemed to be very important for the students 
JARHE 14,1

420

to act empathically. As educators, we need to be more responsive in supporting future professionals in their work to assist clients in navigating their demanding life situations. Empathy needs action as well as boundaries.

According to the study, students became more aware of emotions; of their own, their clients' and coworkers'. Professional empathy is a significant component of the Qualified Empathy skills. During the intervention, the benefit of developing accurate Qualified Empathy was seen as one way to avoid over-empathizing and personal distress. As summarized in Figure 2, in the Qualified Empathy framework, the progression of Qualified Empathy is categorized thematically as (1) from emotional reaction to emotional response, (2) from understanding to empathic acting and (3) from client perspective to a more systematic approach (including the workers themselves, co-workers and eco-social/global perspective). Developing Qualified Empathy is about fine-tuning the skills for achieving change and influence from a wider perspective - the systemic approach - in an empathic way. Although students reflected on their learning in a more profound way, we underscored that maintaining the skill is a lifelong process; continuing reflection is needed.

\section{Discussion}

In this study, as in all studies, some limitations need to be taken into account. One limitation of this study is the size and "nature of data". Secondly, challenges with the concept of Qualified Empathy need to be addressed and more research is needed to define it more concretely. Even so, as it is a new concept, we need more discussion on the differences in the definition of empathy and Qualified Empathy. However, this study offers one new perspective for discussion which is the need for empathy training, in social work education practices and in the field.

An important ethical aspect of research emphasizes that its implementation must not be to the detriment of the people being researched (Juuti and Puusa 2020, pp. 168). In all the various stages of our study, we paid attention to diligence and accuracy, transparency and respect for the work of others. In particular, we have considered our relationship as researchers and teachers, in the development and application of a new concept or approach. We have asked ourselves what is Qualified Empathy and what is empathy? Why do we need Qualified Empathy, isn't empathy enough? No, not in the professional context. We do not believe so as action is not directly needed to empathize.

We are aware of our intermittent subjectivity toward the subject under discussion. The chosen research methods, concepts and methodological solutions required serious discussion. The article was written in many different stages, and in some cases relatively slowly, as we needed in-depth discussions, e.g., on the ethical and conceptual side of the work. As stated earlier, the students gave their consent to the research both orally and by answering the e-questionnaire, which provided information about the research and its utilization. We also informed students about the preservation and handling of the material. The material was collected as part of the courses on the institution's e-form, where it is also stored. Internship reports are retained as a part of teachers' documentation requirements.

Figure 2.

Progression of Qualified Empathy elements

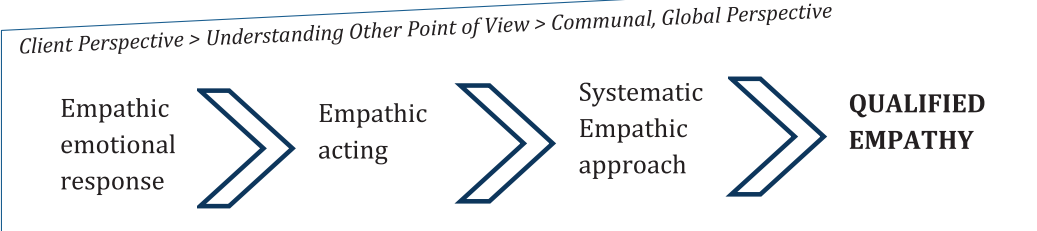




\section{Conclusion}

Our findings demonstrate that educational interventions can improve students' empathy skills to more qualified skills. We emphasized that maintaining the skill demands continuous reflection as a lifelong process. This article provides an overview of an educational intervention to improve students' Qualified Empathy skills and suggests a definition for educators to frame the teaching of professional empathy or empathy in a professional context - especially in the social work context. Furthermore, with this educational intervention in social work, we offer a way to support the students to - not only - have a more professional approach to empathy, but also to find a way to establish a more emotionally sustainable environment for professionals in social services. It is essential for social work education to focus on the growth of Qualified Empathy in students through supervision and guidance which supports their professional competence. By doing so, we contribute to the development of more sustainable working environments in the social work context. Further research should determine whether this measure could be translated into actual changes in student behavior - this might be one-step closer to it.

Moreover, for the students' professional growth, cultivation of empathic intelligence for future professionals, we must first help them as students to experience, understand and improve empathy as a skill. There are many ways to accomplish these goals, for example, art and art education can be seen as methods to support identity review and social awareness. In an era of eco-social crises, contemporary art education can also play an important role as a stimulus for environmental awareness (e.g. Foster et al., 2018). We welcome more research on Qualified Empathy in this broader context. Although the focus is on professional empathy in the social and health fields, the research results can be used more widely in many disciplines as part of professional activities. Professional empathy is seen as an important factor in building a socially sustainable society from the perspectives of employees, clients and patients. We noticed that it is important to allow time and space for the learners to internalize the concept of Qualified Empathy. When we allow for this, students begin to recognize and assign more value to it and, as we suggest, they become more adept in their interactions and work with clients.

\section{ORCID iDs}

Leigh Anne Rauhala Dhttp://orcid.org/0000-0003-1754-0217

\section{References}

Arnold, K. (2014), "Behind the mirror: reflective listening and its Tain in the work of Carl Rogers", The Humanistic Psychologist, Vol. 42 No. 4, pp. 354-369, doi: 10.1080/08873267.2014.913247.

Austring, B.D. and Sørensen, M. (2006), AEstetik og loering - en grundbog om astetiske lacreprocesser (Aesthetics and learning - a textbook on aesthetic learning processes), Hans Reitzels Forlag, Copenhagen, pp. 83-101.

Austring, B. and Sørensen, M. (2011), "A Scandinavian view on the aesthetics as a learning media", Journal of Modern Education Review, No. 2, pp. 90-101.

Austring, B.D. and Sørensen, M. (2009), "Dramaunderviserens mange roller: Hvorfor summer folkeskolen ikke bare af drama?", in Fink-Jensen, I.K. and Nielsen, A.M. (Ed.), AEstetiske Lareprocesser I Teori Og Praksis (1. udg.). Billesøe og Baltzer. available at: http://www. billesoe.dk.

Briggs, C.L., Fox, L. and Abell, C.H. (2012), "The influence of film on the empathy rating of nursing students", International Journal for Human Caring, Vol. 16 No. 2, pp. 59-63.

Cunico, L., Sartori, R., Marognolli, O. and Meneghini, A. (2012), "Developing empathy in nursing students: a cohort longitudinal study”, Journal of Clinical Nursing, Vol. 21, pp. 2016-2025. 
JARHE 14,1
Decety, J. and Jackson, P.L. (2004), "The functional architecture of human empathy", Behavioral and Cognitive Neuroscience Reviews, Vol. 3 No. 2, pp. 71-100.

Eckerman, C.O. and Didow, S.M. (1996), "Nonverbal imitation and toddlers' mastery of verbal means of achieving coordinated action”, Developmental Psychology, Vol. 32 No. 1, pp. 141-152, doi: 10. 1037/0012-1649.32.1.141.

Eichsteller, G. (2010), "The notion of 'Haltung' in social pedagogy", Children Webmag, available at: http://www.childrenwebmag.com/articles/social-pedagogy/the-notion-of-haltung-in-socialpedagogy.

Eisner, E. (2002), The Arts and the Creation of Mind, Yale University Press, New Haven and London, pp. 11-10.

Fonagy, P., Gergely, G., Jurist, E.L. and Target, M. (2004), Affect Regulation, Mentalization and the Development of the Self, Routledge, New York, NY.

Foster, R., Martusewicz, R. and Mäkelä, J. (Eds), (2018), Art, EcoJustice, and Education, Routledge, New York, NY

Finnish National Board on Research Integrity, viewed 30 January 2021, available at: https:/tenk.fi/en/ advice-and-materials/guidelines-ethical-review-human-sciences.

Gerdes, K. and Segal, E. (2009), "A social work model of empathy”, Advances in Social Work, Vol. 10 No. 2, pp. 114-127.

Gerdes, K.E. and Segal, E. (2011), "Importance of empathy for social work practice: integrating new science”, Social Work, Vol. 56, pp. 141-148.

Grant, L., Kinman, G. and Alexander, K. (2014), "What's all this talk about emotion? Developing emotional intelligence in social work students", Social Work Education, Vol. 33 No. 7, pp. 874-889.

Hakim, C. (2000), Research Design: Successful Design for Social and Economic Research, 2nd ed., Routledge, London.

Hepworth, D.H., Rooney, R.H., Rooney, G.D., Strom-Gottfried, K. and Larsen, J.A. (2018), Direct Social Work Practice: Theory and Skills 8th ed.

Howe, D. (2013), Empathy: What it Is and Why it Matters, Palgrave Macmillan.

Iacoboni, M. (2008), Mirroring People, Farrar, Straus \& Giroux, New York, NY.

Juuti, P. and Puusa, A. (2020), "Reliability of qualitative research", in Juuti, P. and Puusa, A. (Eds), Perspectives and Methods of Qualitative Research, Gaudeamus, Helsinki.

King, S. and Holosko, M.J. (2011), "The development and initial validation of the empathy scale for social workers", Research on Social Work Practice, Vol. 22 No. 2, pp. 174-185.

Kolb, D.A. (1984), Experiential Learning: Experience as The Source of Learning and Development, available at: https://www.researchgate.net/publication/235701029_Experiential_Learning_ Experience_As_The_Source_Of_Learning_And_Development.

Lloyd, C., King, R. and Chenoweth, L. (2011), "Social work, stress and burnout: a review", Journal of Mental Health, Vol. 11 No. 3, doi: 10.1080/09638230020023642.

Matthies, A., Närhi, K. and Ward, D. (Eds), (2001), The Eco-Social Approach in Social Work, SoPhi, Jyväskylä.

Newell, J.M. and Nelson-Gardell, D. (2014), “A Competency-based approach to teaching professional self-care: an ethical Consideration for social work educators", Journal of Social Work Education, Vol. 50, pp. 427-439, doi: 10.1080/10437797.2014.917928.

Passarelli, A. and Kolb, D. (2012), "The learning way: learning from experience as the path to lifelong learning and development", The Oxford Handbook of Lifelong Learning. doi: 10.1093/oxfordhb/ 9780195390483.013.0028.

Raatikainen, E., Rauhala, L. and Mäenpää, S. (2017), "Qualified Empathy - a key element for an empowerment professional”, Teoksessa Hämäläinen, J. (toim.), Vuosikirja 2017. Sosiaalipedagoginen aikakausikirja, vuosikirja 2017, pp. 113-122. 
Räsänen, M. (2008), Kuvakulttuurit Ja Integroiva Taideopetus, Vol. 83, Taideteollisen korkeakoulun julkaisu B 90. Helsinki, Gummerus Kirjapaino Oy, Jyväskylä.

Robson, C. (2012), Real World Research, Third Edition, Winley, John Wiley Sons, Cornwall.

Rogers, C. (1961), On Becoming a Person, Houghton Mifflin, Boston.

Rogers, C.R. (1975), "Empathic: an unappreciated way of being”, The Counselling Psychologist, Vol. 5 No. 2, pp. 2-10.

Rogers, C.R. (2007), "The necessary and sufficient conditions of Therapeutic personality change", Psychotherapy: Theory, Research, Practise, Training, Vol. 44, pp. 240-248, Original publication: Journal of Counselling Psychology, 1957, 2, pp. 95-103.

Ruben, J. (2015), “Can Social work students learn empathy?”, Social Work Today, Vol. 15 No. 2.

Ryan, G.W. and Bernard, H.R. (2003), "Techniques to identify themes”, Field Methods, Vol. 15 No. 1, pp. 85-109.

Salonen, A. and Konkka, J. (2015), "An ecosocial approach to well-being: a solution to the wicked problems in the era of anthropocene", Foro de Educación, Vol. 13 No. 19, julio-diciembre 2015, pp. 19-34.

Schön, D.A. (1987), Educating the Reflective Practitioner, Jossey Bass, San Francisco, CA.

Shapiro, J., Morrison, E.H. and Boker, J.R. (2004), "Teaching empathy to first year medical students: evaluation of an elective literature and medicine course", Educational for Health, Vol. 17 No. 1, pp. 73-84.

Sinclair, S., Raffin-Bouchal, S., Venturato, L., Mijovic-Kondejewski, J. and Smith-MacDonald, L. (2017), "Compassion fatigue: a meta-narrative review of the healthcare literature", International Journal of Nursing Studies, Vol. 69, pp. 9-24.

Stanley, S. and Mettilda, G.B. (2015), "Stress, anxiety, resilience and coping in social work students", Social Work Education: International Journal, Vol. 35, pp. 78-88.

Thompson, N. and Woods, H. (2000), Working with People with Learning Disabilities: Theory and Practice, Jessica Kingsley, London / New York, NY.

Trad, M. (2013), "Teaching communication skill and empathy through engaged Scholarship", Radiation Therapist, Vol. 22 No. 1, pp. 21-31.

Wagman, M.A., Geiger, J.M., Shockley, C. and Segal, E.A. (2014), "The role of empathy in burnout, compassion, Satisfaction, and secondary Traumatic stress among social workers", Social Work, Vol. 60 No. 3, pp. 201-209.

Walby, K. and Luscombe, A. (2018), "Ethics review and freedom of information requests in qualitative research", Research Ethics, Vol. 14 No. 4, pp. 1-15, doi: 10.1177/1747016117750208.

Winefield, H.R. and Chur-Hansen, A. (2000), "Evaluating the outcome of communication skill teaching for entry-level medical students: does knowledge of empathy increases?", Medical Education, Vol. 34, pp. 90-94.

Yin, R.K. (2009), Case Study Research: Design and Methods, 4th ed., Sage, Thousand Oaks, CA.

\section{Further reading}

Qualified Empathy, available at: https://www.metropolia.fi/en/research-development-and-innovation/ all-projects/qualified-empathy/

\section{Corresponding author}

Eija Raatikainen can be contacted at: eija.raatikainen@metropolia.fi

For instructions on how to order reprints of this article, please visit our website:

www.emeraldgrouppublishing.com/licensing/reprints.htm

Or contact us for further details: permissions@emeraldinsight.com 